\author{
MARYLA BIENIEK-MAJKA \\ ANDRZEJ CZYŻEWSKI \\ ANNA MATUSZCZAK
}

\title{
National and EU budget \\ expenditures supporting the organisation of the \\ fruit and vegetable market \\ in Poland after 2010
}

Maryla Bieniek-Majka, Ph.D., Kujawy and Pomorze University in Bydgoszcz, Institute of Economic Science,

Poland,

ORCID: 0000-0003-1448-7406.

Prof. Andrzej Czyżewski, University of Zielona Góra,

Poland,

ORCID: 0000-0002-6233-6824.

Anna Matuszczak, Ph.D. PUEB

Professor Extraordinarius, Poznań University of Economics and Business,

Department of Macroeconomics and Agricultural Economics,

Poland,

ORCID: 0000-0002-5045-5447.
"Cooperation is not a sentiment - it is an economic necessity"

Charles Steinmetz

\section{Introduction}

Horticultural products are of material significance to the national agricultural production and have the second largest share - after meat and meat products - in the national export of agricultural products and foodstuffs (Nosecka, 2017, 5). In the conditions of European integration, the development of rural areas and agriculture largely depends on the amounts of transfers from the national and EU budgets, which create opportunities to initiate modernisation processes in agriculture, which in turn should increase the competitiveness of Polish farms (Grzelak, Wiktorowicz, 2009, 21). Poland's accession to the EU and Polish agriculture coming under CAP mechanisms created opportunities for considerable transfers for agriculture and rural areas, which is of crucial importance to the transformations of agriculture and rural areas (Zegar 2018, 308). As Klepacki and Krajewski $(2015,136)$ emphasise, in the case of 
horticulture, producer groups and organisations play a significant role in the modernisation processes. Their dynamic technological development would not be possible without the funds obtained from the EU. Establishing larger economic organisations in agriculture is particularly important with reference to entities selling agricultural products directly in foreign markets and in the domestic market. Offering large product batches (primarily dessert fruit and vegetables) is a sine qua non for their presence in the market (both domestic and foreign) in a situation of a growing level of concentration of the wholesale and retail commercial network in most countries in the world (Nosecka, 2017, 43).

The aim of the article is to discuss the role of national and EU budget resources supporting organisation in the fruit and vegetable market. By way of introduction, the level and dynamics of (national and EU) budget expenditures supporting the agricultural sector in general will be presented. Next, expenditures on the support for the fruit and vegetable market will be analysed in detail in this context. The research period covers the last 10 years (2010-2019), i.e. from the moment when the method of financing the discussed sector changed from an accounting point of view ${ }^{1}$.

\section{Expenditures on the agricultural sector in Poland in the years 2010-2019}

In general, expenditures on agriculture, rural development, and agricultural markets along with the Agricultural Social Insurance Fund (ASIF) and the EU Funds Budget within the analysed 10-year period are characterised by a fading trend. At the same time, it should be stressed that a successive decrease in the share of Poland's agricultural budget in the state's general budget and in Poland's GDP can be observed, in spite of the fact that a growth of the EU Funds Budget in real terms is taking place.

Total expenditures from the national budget on agriculture, rural development, and agricultural markets along with voivodes' budgets, as well as specific reserves and expenditures planned in other budget sections will amount to PLN 9.178 billion in 2019. This constitutes $2.21 \%$ of state budget expenditures excluding ASIF, i.e. the same share as in 2018. It is worth noting, however, that in

1 A change occurred in the functioning of the agricultural budget, as Bank Gospdarstwa Krajowego (BGK) took over the management of the budget of EU funds established on 1 January 2010, thus becoming the central institution dealing with the income and expenditures generated in the settlements with the EU. This resulted in the separation of these funds from the income, expenditures, and deficit of the national budget. 
2017 , it was $2.52 \%$, in $2016-2.28 \%$, in $2015-2.66 \%$, in $2014-3.33 \%$, in $2013-3.36 \%$, in $2012-3.52 \%$, in $2011-4.04 \%$, and in $2010-4.45 \%$ (Czyżewski, Matuszczak, 2015). Therefore, the share of the agricultural budget in the state budget excluding ASIF in 2019 will be lower by $0.31 \%$ than in 2017, and within the last 10 years, the decrease amounted to ca. $40 \%$ compared to 2010. With budget expenditures on ASIF included, the total amount of expenditures grows to PLN 26.879 billion, i.e. is lower by $1.74 \%$ than in 2018 in real terms - the successive decrease of this amount has remained within the range of $1-5 \%$ every year since 2010 . With expenditures on ASIF included, the share of the agricultural budget in state budget expenditures is $6.46 \%$, again lower than in the previous years.

When it comes to the share of the total expenditures on the discussed sector in GDP (excluding ASIF), in 2019, it will be $0.41 \%$ (whereas in 2018 , it was $0.42 \%$, in $2017-0.50 \%$, in $2016-0.44 \%$, in $2015-0.51 \%$, in $2014-0.64 \%$, in $2013-0.67 \%$, in $2012-0.72 \%$, in $2011-0.84 \%$, and in $2010-0.98 \%$ ). So in relation to GDP, the share is at its lowest in 10 years and over half its level of 2010. With expenditures on

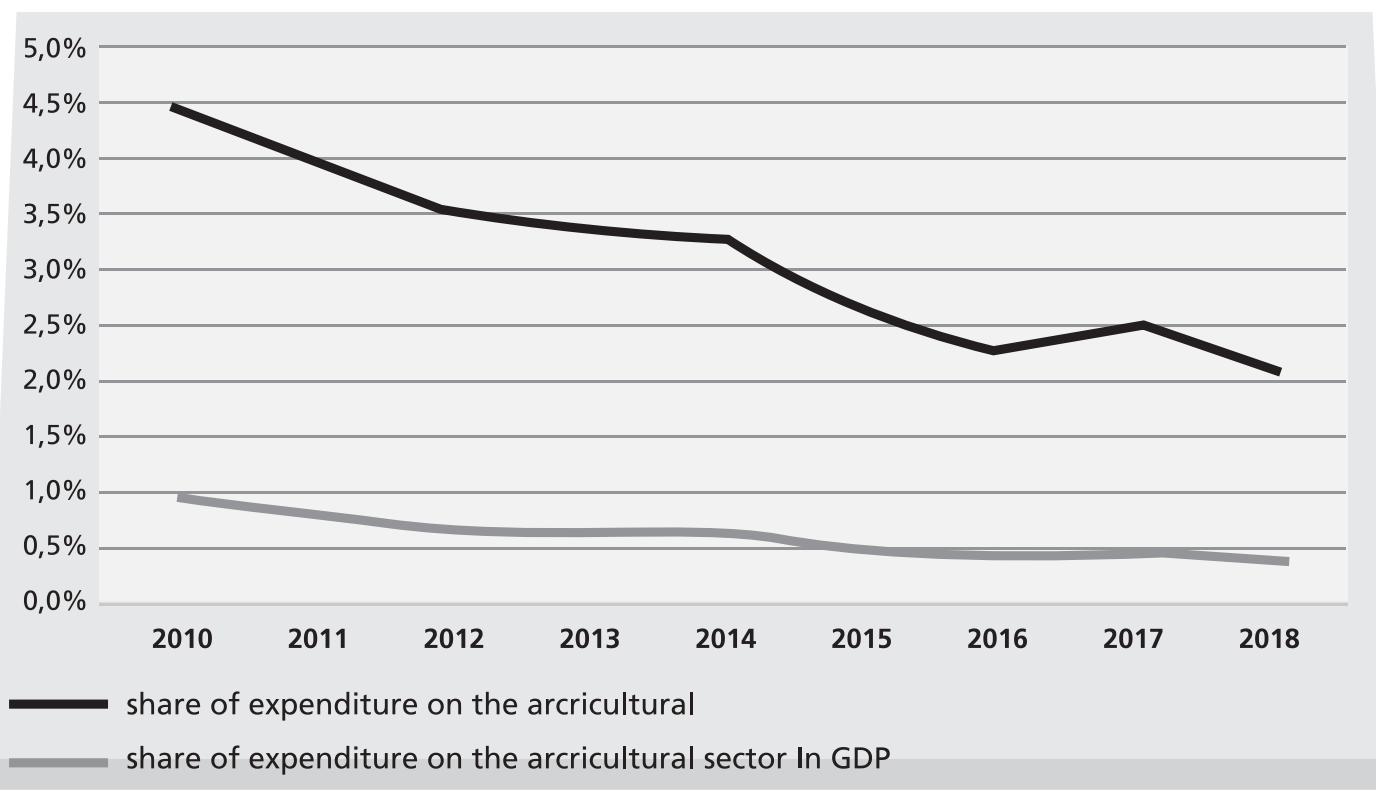

Figure 1. Share of expenditures on the agricultural sector in the total budget expenditure and GDP 2010-2018

Source: authors' own elaboration based on: Projekty Ustaw budżetowych na lata 2010-2019 (Budget Bills for the years 2010-2019) and Uzasadnienia do Ustaw budżetowych na lata 2010-2019 (Explanatory memorandums to Budget Acts for the years 2010-2019), Vol. 1.

(downloaded from http://www.mf.gov.pl) 
ASIF included, the share in 2019 will be $1.2 \%$ (compared to $1.27 \%$ in $2018,1.42 \%$ in $2017,1.43 \%$ in $2016,1.49 \%$ in $2015,1.69 \%$ in $2014,1.67 \%$ in $2013,1.7 \%$ in $2012,2.0 \%$ in 2011, and 2.1\% in 2010).

Also in this case, it will be the lowest in 10 years - 57\% lower than in 2010. A more general conclusion comes to mind in view of the above comparisons: within the last decade, the agricultural budget has been successively decreasing in terms of the share relative to GDP, which shows that the agricultural sector has not been taking advantage of the effects of GDP growth in Poland proportionally (Czyżewski, Matuszczak, 2013). If it was not for the financial support (though decreasing) from the EU funds budget, sector disproportion in the distribution of funds from the national income would increase even more clearly. This may partially be attributed to the adjustments to the current conditions caused by the need for financial limitations in connection with the state's current social spending, yet the scale of reduction is too big and disproportionate, in particular taking into consideration the successive GDP growth in the recent years $(3.8 \%$ in 2018, over $4 \%$ in 2017).

It is worth adding that the analysis of the share of expenditures on the agricultural sector in state budget expenditures shows that integration with the EU was of crucial significance to the changes in the trend in perceiving its funding by decision-makers. Up until 2003, opinions on budget acts (Czyżewski 1997-2016) engendered pessimism. There were reasons to believe that irrational cooling down of the economic situation after 1997 put agriculture in the face of growing crisis. In fact, since the very beginning of the economic transformation in Poland, it has been difficult to say that agriculture was a priority in the government's policy (Czyżewski, Matuszczak, 2014a). The share of expenditures on the agricultural sector in budget expenditures demonstrated a stagnation trend, with dangerous decreases, such as in 2002 - to a level below $2 \%$. The situation changed radically after 2004. Thus, Poland's membership in the EU is reflected in the expenditure plan for their co-financing and pre-financing in the EU Funds Budget (Czyżewski, Matuszczak, 2014b). Within the scope of expenditures from this budget, the 2018 budget bill provides for spending of a total of nearly PLN 21.5 billion, which is an amount higher by $4.03 \%$ in real terms than in 2017, when the EU Funds Agricultural Budget provided for expenditures of PLN 20.2 billion. When it comes to general expenditures planned in Poland's agricultural budget, as pointed out above, they will amount to PLN 48.74 billion, which means that in 2018, they will be lower by $1.63 \%$ in real terms than in 2017 (inflation-corrected), when they were lower by $11.24 \%$ than in 2016 , when

National and EU budget expenditures supporting the organisation of the fruit and vegetable market in Poland after 2010 
they amounted to PLN 53.76 billion. Therefore, the share of expenditures from the EU Funds Budget in 2018 will be 45.16\%, whereas in 2017, it was $42.97 \%$, and in $2016-50.44 \%$. In 2018, just like in 2017, there can be no question of a multiplication of the National Agricultural Budget and the EU Funds Budget, which occurred in 2016, when the amount of EU funds exceeded the amount of national funds for the agricultural sector.

It should be added to the above discussion that Poland's membership in the EU is reflected in the expenditure plan for their co-financing and pre-financing in the EU funds budget.

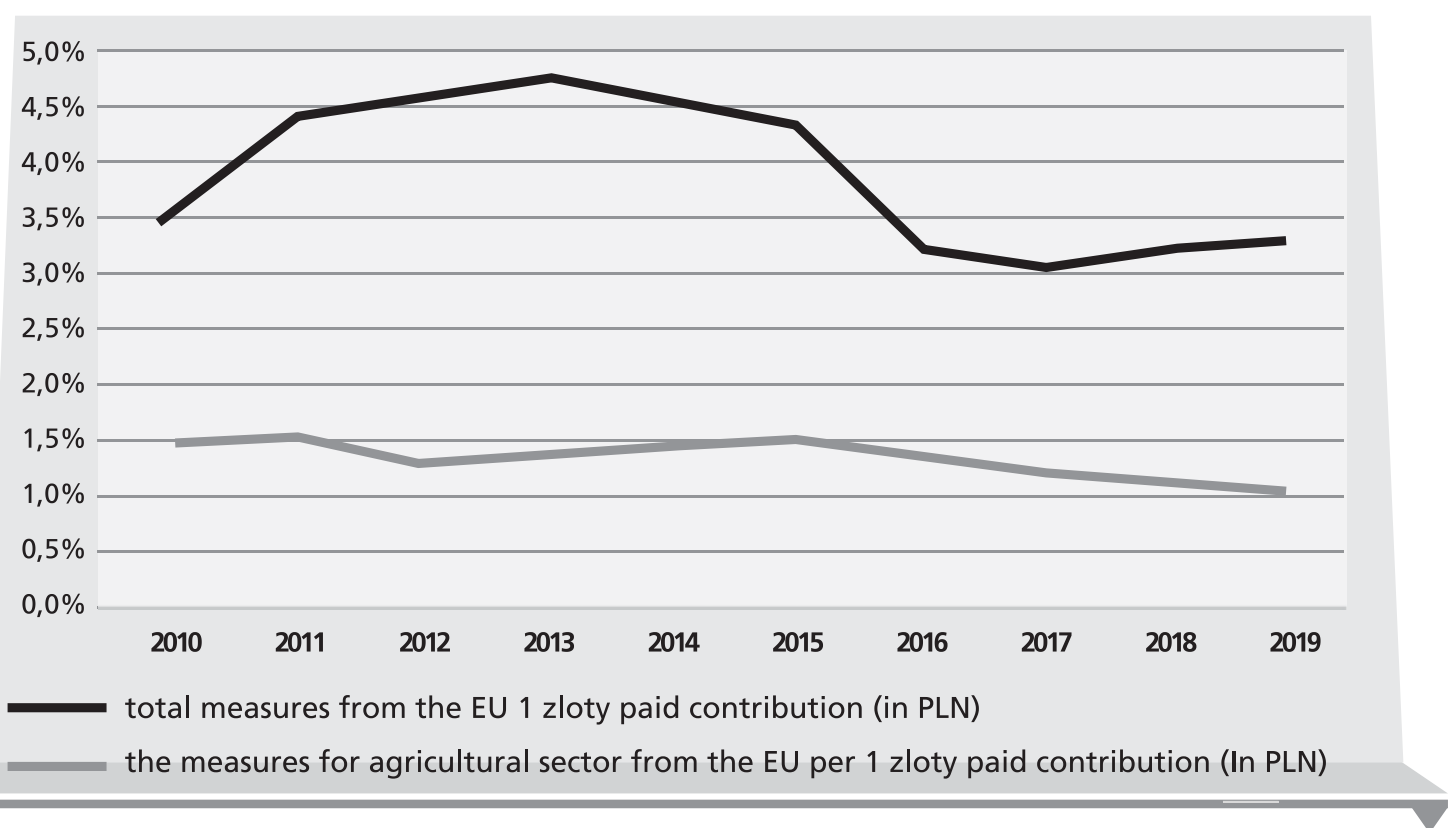

Figure 2. Total EU fund inflows, including the agricultural sector, per PLN 1 of contributions paid (in PLN) in the years 2010-2019

Source: authors' own elaboration based on: Projekty Ustaw budżetowych na lata 2010-2019 (Budget Bills for the years 2010-2019) and Uzasadnienia do Ustaw budżetowych na lata 2010-2019 (Explanatory memorandums to Budget Acts for the years 2010-2019), Vol. 1. (downloaded from http://www.mf.gov.pl)

Within the scope of expenditures from this budget, administered by the Minister of Agriculture and Rural Development, the 2019 budget bill provides for total spending of PLN 20.258 billion. The benefits of the Polish agricultural sector are maintained in 2019, although they are increasingly smaller. It can be estimated that assuming that per every PLN 1 of contributions to the EU's general 
budget paid by Poland in 2019, there will be PLN 3.29 from the funds provided by the EU (in 2018, it was PLN 3.30, in 2017 - PLN 3.08, in 2016 - PLN 3.20, in 2015 - PLN 4.36, in 2014 - PLN 4.52, in 2013 - PLN 4.73, in 2012 - PLN 4.64, in 2011 - PLN 4.56, and in 2010 - PLN 3.48), out of this, PLN 0.96 (proportionally to the $29.08 \%$ share of the agricultural sector in the EU funds) will be allotted to the objectives and tasks of the agricultural budget in Poland. In the previous years, the respective numbers were: in 2018 - PLN 1.09, in 2017 - PLN 1.15, in 2016, PLN 1.41, in 2015 - PLN 1.57, in 2014 - PLN 1.47\%, in 2013 - PLN 1.36, in 2012 - PLN 1.32, in 2011 - PLN 1.53, and in 2010 - PLN 1.50, whereas the arithmetic mean for the years 2010-2019, i.e. a period of 10 years, comes to PLN 1.24. It can be concluded from the above that the decrease in the level of benefits from PLN 1.5 in 2010 to PLN 0.96 in 2019 over the past ten years, per PLN 1 of contributions to the EU budget, i.e. ca. PLN 0.55 less, which is nearly ${ }^{1} /{ }^{\prime}$, should be considered as large, the largest in the last 10 years.

\section{The level and dynamics of financing fruit and vegetable producers from national and EU funds in the years 2010-2019}

As mentioned above, one of the factors considerably supporting the income of agricultural producers is horizontal integration. One of its forms is organising farmers into groups. Horizontal relations between agricultural entities and their joint activities within economic organisations make it possible to break the barrier of the supply scale in agriculture. According to Nosecka $(2017,43,90)$, they allow broadening the scope of instruments used by agricultural entities to compete for marketing, logistics, and qualitative activities ensuring that market requirements are met. It should be borne in mind, however, as pointed out by Czyżewski and Guth $(2016,24)$, that these groups are still too weak to defend the interests of farmers in real terms and to balance their position in the food production chain, because there is a certain kind of asymmetry of concentration, which works to their disadvantage. According to Woś, carrying out such activities independently is not possible even for agricultural producers with farms with a relatively large production and supply scale, which is why he believes that the need to support the process of concentration of supply of agricultural products, including horticultural products, which is too slow as a result of macroeconomic factors, should be emphasised.

Macro-level (independent) factors include: the system in which the state functions (the state's financial condition, the efficiency of governmental organisations, freedom of establishment); the activity of units making up the

National and EU budget expenditures

supporting the organisation of the fruit and vegetable market in Poland after 2010 
institutional environment of food companies and farms. In the extensive list of these external (independent) factors evaluated at the level of the economy, the general condition of the economy, particularly the financial condition (including GDP growth rate, inflation rate), is of the most importance to the agricultural sector and the entities which function within it. The financial condition of EU Member States determines the extent to which the level of support for the sector from the national resources, stipulated by EU legislation, is used (Nosecka, 2017, 37,45). It should be noted that the EU budget differs from national budgets. The EU does not directly fund the tasks which are to be carried out within the framework of the national fiscal policy as part of its redistribution function. The EU budget is based on assumptions which are pan-European in nature. Expenditures are precisely addressed, which makes it possible to concentrate on the fields in which the funds spent bring added value expected by the EU. Therefore, the activities which are financed are those which legitimise the functioning of the EU and their execution is more effective thanks to joint funding and control. This is why the budget supports, among other things, common policies that Member States decided to implement together at EU level, such as the CAP (Czyżewski, Matuszczak, 2014, 39), which included a programme supporting the process of fruit and vegetable market organisation.

In Poland, as of 31 December 2018, there was one group granted preliminary recognition and 271 recognised fruit and vegetable producer organisations (including one association of organisations). The financial aid for recognised fruit and vegetable producer organisations provided to co-finance the operational fund amounted to PLN 51.2 billion by the end of 2018, whereas the fruit and vegetable producer groups granted preliminary recognition received PLN 7,911,410.40 (including PLN 362,917.90 to cover the costs related to the establishment of the producer group and its administrative operations and PLN 7,548,492.50 to cover part of the eligible costs of investments included in the approved recognition plan). ${ }^{2}$ Nosecka $(2017,73)$ points out that Polish horticulturists were the biggest beneficiary of this EU programme, as they absorbed $95 \%$ of the total support paid out to these units. However, the amounts provided to fruit and vegetable producers raise the question of whether transfers concentrated in commercial farms with a large production scale are justified. Zegar $(2018,363)$ emphasises that the transfer of funds to an on average poorer taxpayer enriches the wealthier agricultural producers, particularly in a situation in which the effectiveness of these funds is unclear. Our previous studies (Bieniek-Majka, Matuszczak, 2017)

2 www.arimr.gov.pl download date: 15 January 2019 
have shown that there are cases in which an overinvestment was made. However, pointing to the importance of achieving the optimal relation of technology to the given area and the evaluation of the economic benefits of giving preference to larger farms in the allocation of public fund transfers, taking into consideration the disadvantages for smaller farms, Zegar $(2018 ; 363,372)$ stresses that the general principle should be to strengthen the farms with development potential. In the conditions of the dominance of corporations in food chains (vertical integration), reasoning would require horizontal cooperation, as the scale of production in family farms may turn out to be too small. It is therefore justified to support producer groups, as well as various cooperatives in the sphere of production, trade, and services. A revival of agricultural cooperative movement should also be supported, as it benefits farmers in many developed countries. Undertaking activities in these areas may encounter difficulties resulting from market dominance, with strong economic support for farms in other countries and the neoliberal ideology coining slogans about freedom, ownership rights, and equality before the law.

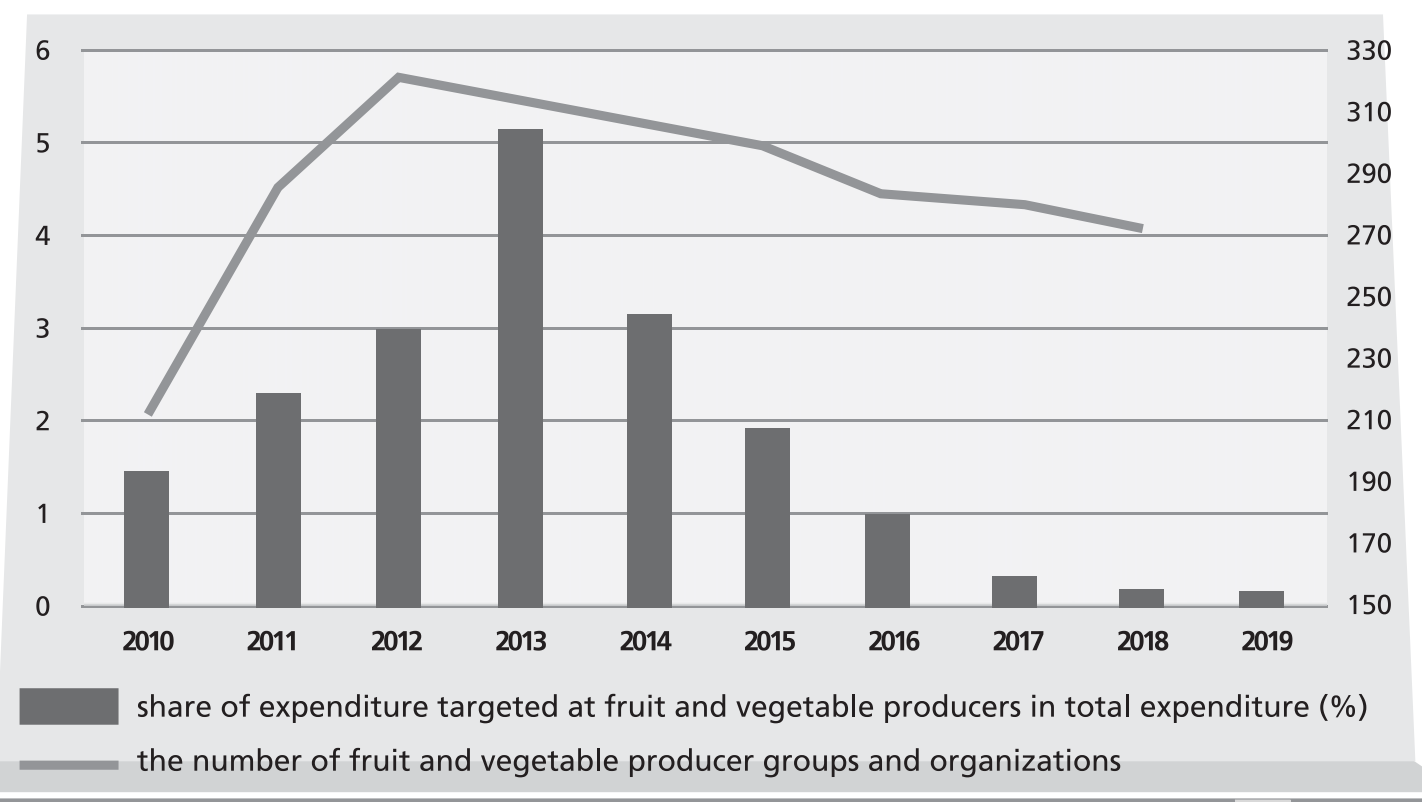

Figure 3. Number of fruit and vegetable producer groups and the share of funds for fruit and vegetable producers from the national and EU budgets in Poland after 2010

Source: authors' own elaboration based on the data available in the Register of producer groups granted preliminary recognition, recognised producer organisations and their associations, and supranational producer organisations and their associations kept by the President of the Agency for Restructuring and Modernisation of Agriculture (ARMA) and Budget Bills for the years 2010-2019 
In the light of the above, more questions arise: what is the trend in supporting fruit and vegetable producers from public funds?; was the process of organising the fruit and vegetable market determined by the expenditures from the national and EU budgets? We may look for answers in the data presented in fig. 3.

However, before we answer the basic questions, it should be mentioned that in 2007, pursuant to Council Regulation (EC) No. 1234/2007, funds for establishing a common organisation and covering the eligible investment costs were offered to producers willing to integrate, amounting to $75 \%$ of the costs incurred (50\% from the EU budget and 25\% from the national budget). This money flow financing investments in the fruit and vegetable sector was drastically decreased pursuant to Commission Implementing Regulation (EU) No. 302/2012 of 4 April 2012. The link between the legislative changes and the number of functioning fruit and vegetable producer groups and organisations in Poland can be seen in figure 4 below. Taking into consideration the fact that the Pearson (linear) correlation coefficient between the analysed variables has a value of 0.53 , we can conclude that the number of fruit and vegetable

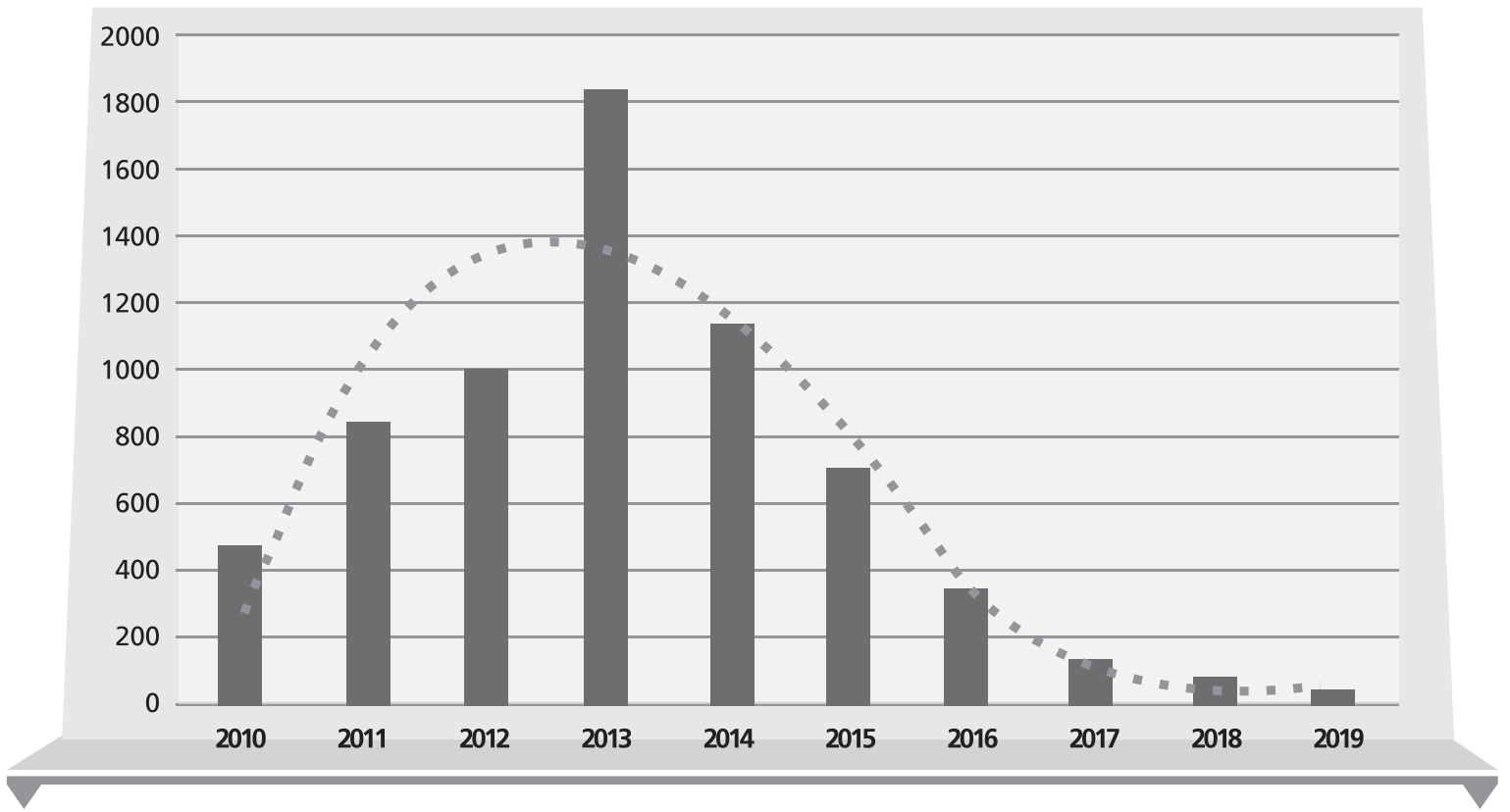

Figure 4. Expenditures on the organisation of the fruit and vegetable market in Poland after 2010 (in thous. PLN)

Source: authors' own elaboration based on the data available in the Register of producer groups granted preliminary recognition, recognised producer organisations and their associations, and supranational producer organisations and their associations kept by the President of the Agency for Restructuring and Modernisation of Agriculture (ARMA) and Budget Bills for the years 2010-2019 
producer groups and organisations in Poland is largely determined by the amount of funds received from the national and EU budgets. It can also be said that expenditures on the support of fruit and vegetable producers from the national budget were "forced" by implementing EU programmes, as the state's own contribution was required.

In our opinion, on account of its scale, the programme supporting the initiation of integration activities among horticulturists inspired them to establish fruit and vegetable producer groups and organisations. However, looking at the degree of their longevity in the market, it needs to be said that the programme was too short. Agriculture, particularly horticulture, is highly exposed to agrometeorological factors, which is why it should be covered by long-term interventionism, making it possible to eliminate fluctuations resulting from factors beyond the horticulturists' control. A continuation of the support (extended in time) should be suggested in order to create favourable conditions for further organisation of the fruit and vegetable market, as compared to the highly organised markets in Northern European countries (such as Denmark or the Netherlands), its level is insufficient, which leads to lowered competitiveness of Polish horticulturists in the international arena. This is also confirmed by Nosecka $(2017,45)$, who points out that without external support and financial incentives, the acceleration of the process of breaking the barrier of the scale of production in farms by creating larger economic entities - producer groups and organisations - is rather unrealistic. All the more so because the number of groups and organisations is dropping. In the register kept by the President of the Agency for Restructuring and Modernisation of Agriculture (ARMA), we can see that since the beginning of the implementation of the programme, 344 units were established, whereas by the end of 2018, there were only 272, which means that the number has decreased by nearly $21 \%$. Admittedly, already after 2012, the then European Commissioner for Agriculture and Rural Development, Dacian Ciolos, claimed that a growing level of concentration can be achieved by increasing the number of members of the existing groups, without creating new ones (Bieniek-Majka, $2012,10)$, yet in Poland, the number of members dropped by as much as $27 \%$. It seems that the process of concentration in the fruit and vegetable market is in a critical phase. If the competitive advantage of Polish horticulturists gained over the years is to be maintained, the sector should receive support. It is not an easy one, as it is characterised by a complex production structure and the cultivation of horticultural products requires extensive specialist knowledge. Therefore, Nosecka $(2017,71)$ also observes the need to provide funds for the 
development of science within this field. She emphasises that unfortunately, the decreasing share of funds for $\mathrm{R}+\mathrm{D}$ and the decrease in employment in the $\mathrm{R}+\mathrm{D}$ sphere in agriculture is markedly unfavourable in this context. Thus, it is difficult to understand the state's policy which - with growing GDP (as mentioned above, ca. 4\% a year in the recent years) - allots less and less funds for the maintenance (not to mention further development) of the level of organisation of the fruit and vegetable market. This is yet another proof that agriculture is marginalised in the distribution of the effects of economic growth.

\section{Conclusions}

Based on the above discussion, it can be concluded that:

1. Within the last decade, support for the agricultural sector, both from the national and the EU budget, has been successively decreasing. The amount of this support measured by the share of total expenditures on the agricultural sector in GDP decreased twofold, just like the share of these expenditures in total budget expenditures. At the same time, the stream of funds flowing into the sector from the EU decreased by $1 / 3$ per PLN 1 of contributions paid.

2. The analysis of funds for the support of the organisation of the fruit and vegetable market, which is one of Poland's more important agricultural markets, shows that a relatively large stream of financial support, aimed at initiating and enhancing its horizontal integration, flowed into the sector in a relatively short time.

3. Unfortunately, as statistics show, this did not make it possible to achieve the set objectives to the full extent - the support was intensive, but short-term, plus at the same time, Polish farmers faced more exogenous difficulties, resulting both from the political situation (the ongoing embargo imposed by the main recipient of horticultural products, Russia, in effect since 2014) and the intensifying climate change (prolonged precipitation, drought, shifting seasons). At the same time, maintaining a competitive position and not wasting the resources invested to date requires Polish horticulturists to change the planting arrangements (varieties), among other things, which involves more investments.

4. Taking into consideration the fact that the recent years saw a growth of the entire economy, it was a period of a definite slowdown in the horticultural sector. Thus, it is difficult to expect an increase in investments without a structural approach to the issue of constant deficiencies in the organisation 
of the fruit and vegetable market and a lack of long-term financial and institutional stimulation.

\begin{abstract}
National and EU budget expenditures supporting the organisation of the fruit and vegetable market in Poland after 2010

The aim of the article is to discuss the role of national and EU budget resources supporting organisation in the fruit and vegetable market. By way of introduction, the level and dynamics of (national and EU) budget expenditures supporting the agricultural sector in general was presented. Next, expenditures on the support for the fruit and vegetable market were analysed in detail. The research period covered the years 2010-2019. The authors pointed to the progressive decrease in spending on the agricultural sector in Poland, both from national and EU funds. At the same time, the support provided to the title sector was relatively large, but rather short-term, which made the formation and consolidation of the desired structures within the framework of horizontal integration impossible.
\end{abstract}

Keywords: national budget expenditure, EU expenditure, fruit and vegetable market.

\title{
Streszczenie
}

\section{Krajowy i unijny budżet rolny Polski po 2015 r. redukcja wydatków i kierunki zmian}

Celem artykułu jest wskazanie na rolę wydatków z budżetu krajowego i budżetu UE wspierających organizację rynku owoców i warzyw. Jako wprowadzenie przedstawiono poziom i dynamikę wydatków budżetowych (krajowych i unijnych) wspierających sektor rolny w ogóle. Następnie szczegółowo przeanalizowano wydatki na wsparcie rynku owoców i warzyw. Okres badań obejmował lata 2010-2019. Autorzy wskazali na postępujące zmniejszanie wydatków na sektor rolny w Polsce, zarówno z funduszy krajowych, jak i unijnych. Jednocześnie wsparcie sektora tytularnego było stosunkowo duże, ale raczej krótkoterminowe, co nie pozwalało na tworzenie i konsolidację wymaganych struktur w ramach integracji horyzontalnej. 


\title{
Słowa
}

kluczowe: $\quad$ wydatki budżetu państwa, wydatki UE, rynek owoców i warzyw.

\section{JEL}

\author{
Classification: Q01, Q13, F36
}

\section{References:}

1. Bieniek-Majka, M. (2012). Grupy producentów owoców i warzyw w nowej perspektywie finansowej (Fruit and vegetable producer groups and the new financial perspective), Roczniki Naukowe Stowarzyszenia Ekonomistów Rolnictwa i Agrobiznesu vol. XIV, no. 2, pp. 7-10,

2. Bieniek-Majka, M., Matuszczak, A. (2017). Integracja pozioma na rynku owoców $i$ warzyw na przykładzie województwa kujawsko-pomorskiego (Horizontal integration in the fruit and vegetable market on the example of the Kujawsko-Pomorskie voivodeship), Bydgoszcz: Wydawnictwo KPSW in Bydgoszcz

3. Czyżewski A., Matuszczak A. (2013). Dochody i wydatki w budżetach rolnych Polski w mijającej perspektywie finansowej 2007-2013 (Income and expenditures in Poland's agricultural budgets in the financial perspective 2007-2013). Journal of Agribusiness and Rural Development, 2(28), pp. 33-44.

4. Czyżewski A., Matuszczak A. (2015). Potrzeba zmian w modelu rozwoju rolnictwa a finansowanie celów w budżecie rolnym Polski po 2005 roku (The need for changes in the model of agricultural development and the financing of objectives in the Polish agricultural budget after 2005). Studia Ekonomiczne. Zeszyty Naukowe Uniwersytetu Ekonomicznego w Katowicach, no. 218, pp. 113-132. Downloaded from: http://www.ue.katowice.pl/ uploads/media/08_18.pdf.

5. Czyżewski, A. Matuszczak, A. (2014). Krajowe i unijne wydatki budżetowe na sektor rolny $\mathrm{w}$ Polsce (National and EU budget expenditures on the agricultural sector in Poland), Roczniki Naukowe Ekonomii Rolnictwa i Rozwoju Obszarów Wiejskich, Vol. 101, No. 2, pp. 37-44.

6. Czyżewski, A. Matuszczak, A. (2018). Wydatki budżetowe na rolnictwo, rynki rolne, rozwój wsi i KRUS w warunkach zmieniającej się opcji $\mathrm{w}$ polityce gospodarczej w Polsce (Budget expenditures on agriculture, agricultural markets, rural development, and ASIF in the conditions of the changing options in Poland's economic policy), Roczniki Naukowe Stowarzyszenia Ekonomistów Rolnictwa i Agrobiznesu, TXX(3), pp. 28-33. DOI: 10.5604/01.3001.0012.1486

7. Czyżewski, A., Guth, M. (2016). Zróżnicowanie produkcji mleka $w$ makroregionach Unii Europejskiej z wyróżnieniem Polski (Diversification of milk production in the macro-regions of the European Union with focus on Poland). Warsaw: Wydawnictwo Naukowe PWN. 
8. Grzelak, M.M. Wiktorowicz, J. (2009). Ocena wsparcia publicznego rolnictwa $\mathrm{w}$ Polsce - wybrane zagadnienia (Selected aspects in the evaluation of public funding for agriculture in Poland) Zeszyty Naukowe SGGWW w Warszawie. Problemy Rolnictwa Światowego vol. 7(22) pp. 21-31

9. Klepacki, B. Krajewski, J. (2015). Wykorzystanie środków pomocowych Unii Europejskiej w rozwoju infrastruktury logistycznej grup producenckich $\mathrm{w}$ ogrodnictwie (The use of the European Union's aid funds in the development of logistics infrastructure of fruit producer groups in horticulture), Roczniki Naukowe Stowarzyszenia Ekonomistów Rolnictwa i Agrobiznesu, TXVII (5), pp. 136-140.

10. Nosecka, B. (2017) Czynniki i mierniki konkurencyjności zewnętrznej sektora ogrodniczego i jego produktów (Factors and measures of external competitiveness of the horticultural sector and its products). Warsaw: IERiGŻ-PIB.

11. Projekty Ustaw budżetowych na lata 2010-2019 (Budget Bills for the years 20102019) and Uzasadnienia do Ustaw budżetowych na lata 2010-2019 (Explanatory memorandums to Budget Acts for the years 2010-2019), T.1. (date accessed 15 January 2019 http:/ / www.mf.gov.pl)

12. www.arimr.gov.pl (date accessed: 15 January 2019)

13. Zegar, J. St. (2018). Kwestia agrarna w Polsce (The agrarian issue in Poland). Warsaw: IERiGŻ-PIB. 